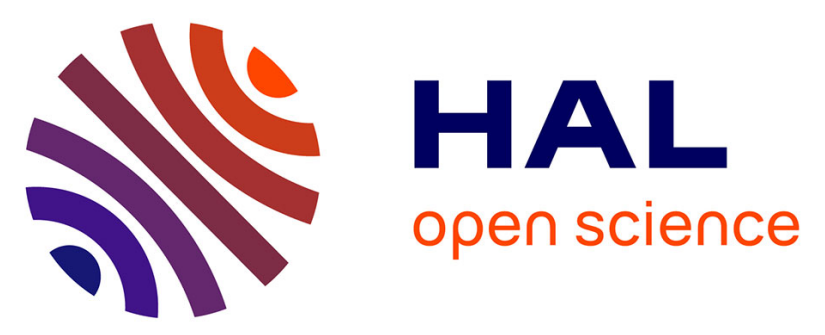

\title{
Identifying a Public Sector Information Systems (PSIS) for E-service: A Case of Land Records E-service in Bangladesh
}

\author{
Muhammad Shahanoor Alam, Laurence Brooks
}

\section{- To cite this version:}

Muhammad Shahanoor Alam, Laurence Brooks. Identifying a Public Sector Information Systems (PSIS) for E-service: A Case of Land Records E-service in Bangladesh. 13th International Conference on Electronic Government (EGOV), Sep 2014, Dublin, Ireland. pp.106-119, 10.1007/978-3-662-444269_9. hal-01401731

\author{
HAL Id: hal-01401731 \\ https://hal.inria.fr/hal-01401731
}

Submitted on 23 Nov 2016

HAL is a multi-disciplinary open access archive for the deposit and dissemination of scientific research documents, whether they are published or not. The documents may come from teaching and research institutions in France or abroad, or from public or private research centers.
L'archive ouverte pluridisciplinaire HAL, est destinée au dépôt et à la diffusion de documents scientifiques de niveau recherche, publiés ou non, émanant des établissements d'enseignement et de recherche français ou étrangers, des laboratoires publics ou privés. 


\title{
Identifying a Public Sector Information Systems (PSIS) for E-service: A Case of Land Records E-service in Bangladesh
}

\author{
M Shahanoor Alam and Laurence Brooks ${ }^{1}$ \\ School of Information Systems, Computing and Mathematics, Brunel University, Uxbridge, \\ Middlesex, UB8 3PH, UK
}

\begin{abstract}
This paper aims to identify the need for Public Sector Information Systems (PSIS), a particular field of the IS discipline dealing with the design, redesign and evaluation of E-services in public sector organizations. A longitudinal and empirical study of an E-service project in a public sector organization in Bangladesh reveals that without addressing underlying organizational problems, taking account into organization contexts, statutes and practices and considering the organizational reality and users' capability; it is difficult to implement E-services in public sector organizations. This paper argues that a particular information system (public sector information systems (PSIS)) has the potential to lead to better design and implementation of successful E-services in public sector organizations.
\end{abstract}

Keywords: land records management, public sector information systems, Bangladesh

\section{Introduction}

With the advancement of information technology (IT) and increasing use of IT for business and organizational purposes, electronic service (E-service) has become a widely used concept across disciplines and academic fields [26], [32]. For example, from buying a book on eBay to online dating or from booking an air ticket to paying council tax can be performed through E-services. However, the forms, process and nature of E-services are vary widely. For example, an email enquiry can be resolved in a few minutes in a business organization while it might take two weeks in the contexts of a public sector organization. According to the nature of an organization, Lindgren and Jansson [26] have categorized E-services into two distinct types: private and public. Private E-services deal with business organizations in particular private sector organizations, whereby clients are considered as customers and profit is the main goal. On the other hand, public E-service is delivered from public sector organizations whereby clients are treated as citizens and services are regulated by organizational and bureaucratic rules. Notably, ensuring citizens' easy access to services is the

\footnotetext{
${ }^{1}$ Corresponding Author.
} 
main goal rather than profit. Thus, significantly, E-services for public sector organizations differ from E-services for private sector organizations. Consequently, designing E-services for public sector organization requires a particular focus on specific features and contexts of public sector organization. The process, volume and complexity of public E-service is distinct from private E-services. Since public sector organizations are guided by a number of regulations, statutes, and processes; it takes a longer time and its process is more complicated. Therefore, this paper seeks to understand what a Public Sector Information System (PSIS) offers in terms of designing Eservices for public sector organizations.

The public sector managers and consultants are often inspired by E-services in private sectors while they only focus on technology; not on the underlying contexts. Consequently, although E-services in public sector organizations have expanded very rapidly; it has remained largely unattainable in the public sector organization in developing countries [3], [14], [23], [32]. More importantly, it is inevitable to understand the information systems and underlying contexts in of public sector organization in order to design E-service for public sector organization. Thus, this paper aims to identify the role of public sector information systems (PSIS) in designing and implementing E-service in public sector organizations.

Efforts of introducing effective service delivery in public sector organization can be traced from New Public Management (NPM) to more recent Electronic Governance (E-Governance). However, Dunleavy [11] claims that NPM is dead; public sector organizations need digital era governance which is synonymous to E-governance. More recently, Lips [27] asserts that E-government is also dead because it is unable to manage transformational change with the use of IT in public sector organizations. Egovernance is not a panacea for enhancing service delivery in public sector organization because designing electronic service delivery without tracing underlying contexts cannot ensure effective service delivery in public sector organizations. Evidently, the rate of E-governance as well as E-service failure is very high. Notably about $85 \%$ of E-governance projects have been failed in the context of developing countries [17]. However, it is not the aim of this paper to identify limitations of E-governance or identify the best approach for designing and implementing E-service in public sector organizations; rather, this paper aims to identify the role of public sector information systems (PSIS) as a complementary approach in designing and implementing Eservice in public sector organizations. Although PSIS is not new it is potential approach for designing and implementing E-service in public sector organizations.

E-service in public sector organization is a complex task. It involves organizational contexts, legal statutes, decision making authority, organizational hierarchy, routines, skills and innovations at work [3], [30], [37]. A PSIS is inevitable to trace underlying organizational processes and contexts of public sector organizations. Public sector organizations are wide and complex, with its core task as service delivery to citizens. More importantly, E-service from public sector organizations is not the same as Eservice in private organizations [26]. E-service from public sector organization involved rules, regulations, bureaucracy, legal statutes, routines and traditions, for example, NHS - National Health Service in the UK, social security service in the US and passport and driving license authorities in almost every country. 
A number of disciplines and fields including E-governance, information systems, management, organization studies and computer science are relevant in designing and implementing E-service applications. However, focuses on the context of public sector organizations and process of service delivery in public sector organization require particular attention due to the nature and wide of public service delivery. Particularly, public sector organizations in many developing countries carry thick bureaucratic processes and heritage from colonial legacies, vested interests of staff and decision makers, rigidity in statutes and structure of organizations [2], [5], [20], [21]. Consequently, designing and implementing E-service in public sector organizations demands more in-depth and wider approach, tools and skills. This paper aims to identify the role of PSIS in designing and implementing E-service in public sector organizations, particularly with a focus on developing countries contexts and illustrated with a case of E-service of land records in Bangladesh, a developing country

The rest of the paper comprises four sections. The following section describes the methodology of data collection and background to the case. This is followed by a brief literature review on public sector information systems (PSIS). The next section illustrates the case of land records E-service delivery in Bangladesh. Finally the paper is concludes by identifying the significance of PSIS in designing and implementing Eservice in public sector organizations.

\section{Methodology and Background}

This paper is the outcome of an interventional and longitudinal study. The authors were involved in designing and evaluating an E-service project in a public sector organization in Bangladesh over the last three years. This study has been conducted through an action design research (ADR) [4], [44] framework which allows the researchers to conduct multiple iterations from problem formulation to designing solution to implementation and evaluation of E-service of land records in a public sector organization.

Thus the ADR methodology has provided the opportunity for conducting close observations of the organizational processes and contexts. Thus researchers chose participant observation, ethnographic and semi-structured interviews methods for data collection. They have conducted participant observation on organizational processes and contexts relating this service delivery. Besides, ethnographic and semi-structured interviews have been conducted with four clerical staff, two managers and six citizens, the service recipients. Since an author was a former employee in the organization and a current researcher, this dual role allowed them to apply interventional and observational methods and approaches.

Throughout, researchers close observation and intervention within this complex organizational context help in problem formulation, implementation and evaluation processes of E-service. Data from this study has been analyzed using a thematic approach, with themes derived both from literature, theories, observation, interventions and interviews. The nature of this study finding is qualitative and findings have been 
presented with thematic and descriptive style. Thus, the study findings has been reported and narrated by the researchers.

This study has been conducted in a public sector organization, namely the District Record Room (DRR) that is responsible for issuing land records to citizens in Bangladesh. The DRR issued certified copies of land records on the basis of citizens' applications. Thus it is called 'land records service'. The land records service in Bangladesh is a core service from the public sector organization for the citizens and every day about 15,000-20,000 citizens need land records. However, this service has a bad reputation for being overly complex, corruption and public suffering which has brought it to the attention of policy makers and development partners. Thus the government has been trying to address these problems through implementing E-service of land records.

\section{E-service Efforts in Public Sector Organization: NPM -E- Governance -Public Sector Information Systems (PSIS)}

Public sector organizations carry a list of distinctive features: labor intensive; broad scope; organizational legacy; bounded with legal statutes, guided by rules and regulations; thick bureaucratic processes and merely any reward for innovation rather risk in innovation and change. Consequently, access to the services of public sector or deliver effective service delivery from public sector has never been easy. Thus a number of studies and evaluation reports suggested that in order to design and implement Eservice for public sector organizations requires tracing underlying contexts of the service; increasing collaboration and cooperation and transforming productivity and efficiency [6], [13], [19], [46]. A number of efforts have been employed in transformation of public sector organization as well as service delivery from public sector organization. This paper mainly focuses on New Public Management (NPM) and Egovernance, whereby service delivery as well as E-service is the main attraction. NPM brought a wave of reform in services in public sector organizations with a view to providing effective and efficient service delivery to citizens [11]. NPM engaged in deliberate changes of structures and processes in public sector organizations to ensure better service delivery [38]. It was mainly management led tools, techniques and strategies. However, NPM failed to keep pace with the dynamism of organizational change and trace the changes relating to technological inducement in public sector organizations [10], [11], [27].

Consequently, NPM was blended with public administration in planning and organizing of management functions and services to achieve quality service through using human and technological resources. Thus, it also focused on decentralization to reduce bureaucratic hierarchy and complications. Further, it introduced competition and ensured rewards and specific performance measures through reforming complicated processes and employing resources. However, NPM brought mechanistic concepts and tools from the ideology of the management of private sector organizations and these were hardly applicable to public sector organizations [12], [29]. Moreover, NPM followed linear directions in designing services from public sector organizations 
but changes in of public sector services is often dynamic and unpredictable. Changes in public sector organization take place through dynamic relations between technology and organizational contexts. Therefore, NPM has failed to integrate its tools and processes into the practice relating to technology and public sector organizations [11]. Electronic governance (E-governance) emerged with the expansion of IT in public sector organization. Therefore, gradually NPM has been replaced by E-governance.

E-governance has become a catchphrase, a discourse and a catalyst to ensure better service delivery to citizens through employing IT in public sector organizations [49]. E-governance refers to interactions between government, citizens, business processes and actors using electronic means with a view to achieving citizens' easy access to public services and ensuring transparency and efficiency in public sector organizations [11], [27], [48], [49]. However, E-governance focuses on governance that refers to the act of governing which include role and interactions between government, private sector and civil society for enhancing service delivery, increasing participation, accountability and transparency. Further, governance is just interstices across private, public and civic sectors and aims to steer the processes that influence decisions and actions across the sectors [33]. E-Governance seeks to provide public services for the ease and option of citizens, keep citizens informed, and solicit their voice in the functioning of government. The ultimate goal is to ensure citizens' stake, to put citizen at the heart of public administration, without any exclusion. However, E-governance cannot harness the advantages of IT implementation without organizational change, legal reforms, participation of staff and resources and citizens' preparedness and engagement. Consequently, the rate of failures of E-governance initiatives is very high [16], [17].

Furthermore, since inception E-governance has been suffering with maintaining the balance between designing organizational processes and employing information technology. Until now, the main focus of E-governance has remained on IT implementation instead of designing and redesigning the organizational processes for effective service delivery. As a result, E-governance failed to take into account the role of organizational contexts. Similarly, Yildiz [48] asserts that E-governance research suffers with oversimplifying of organizational contexts and processes.

Designing E-service in public sector organizations requires understanding of organizational contexts and processes. Since public sector organizations carry thicker bureaucratic processes and complex organizational contexts, E-service cannot be designed in public sector organization rationally, predictably, straightforward and as a linear process, rather it is unpredictable, dynamic and complex [22]. Thus, Egovernance is incapable of tracing dynamic change because it predominantly focuses on technological capabilities and leads with a linear perspective on the usage of Eservice and its impacts and outcomes [27]. Consequently, Lips [27] argues that it is inevitable to think of an alternative stream in E-government [27].

Thus, success and failure of E-governance mainly relies on the design and redesign of organizational processes (legal statutes, regulations, organizational behavior, attitudes, alliances, networks, readiness and participation) along with the technological design. In order to understand organizational processes and contexts of public sector organization, particularly public sector information systems (PSIS) offers potential 
lens. Designing E-service is not only technological design rather it requires taking into account the organizational processes and context.

This paper, thus, seeks relevance of public sector information systems (PSIS) in designing E-service. PSIS is not new but so far it is also not well established. Thus this paper has identified the potential benefits of PSIS in designing and implementing E-service in public sector organizations.

\section{Designing E-services in Public Sector Organizations and PSIS}

Inherently, IS focuses on public sector organization from a holistic view that captures contexts, nature, dynamism and unpredictability in technology and organization. Although information systems (IS) emerged in the 1950s; as a distinct field it developed in the 1970s but it has 'exploded' in the 1990s and it is increasingly expanding with the use of IT in organizational applications [8], [18]. The core of IS is that it acts as the interface between organizational the contextual relations and the use of IT. Thus IS seeks human behavior and technology in relation to understand multifaceted interactions between changing technologies and changing human tasks, goals, preferences and dynamics [31]. Thus, IS can be seen as a bedrock of using IT in public sector organization [18].

The centrality of the IS discipline is to deal with IT in everyday life rather than deeply engaging with purely technical aspects of information technology [36]. Evidently, IS deals with IT and organizational contexts with equal emphasis. More importantly, IS reveals organizational culture, contexts, norms and process that play a trivial role in designing technology for public sector organizations and service delivery for public sector organization [41], [42]. Similarly, Walsham [47] finds that there is strong link between technological processes and contexts of public sector organization in developing countries. However, there is little of agreement on how the technology interacts with organizations [35].

Since the inception of IS discipline, public sector information systems (PSIS) has focus on public sector organizations with inherent characteristics: continuous monitoring, controlling and evaluating (reporting), intervening on the basis of evaluation and applying operational and management [18]. Thus PSIS deals with public sector accounting, human resources, taxation, and public service delivery. In order to manage and monitor public services from public sector organizations, PSIS plays a vital role. For example, while the NHS in UK tries to control costs and simultaneously improve service delivery standards, it does so though PSIS. The role of PSIS is remarkable to accelerate of public service in the UK. Consequently, although in the UK E-government program ended in 2006; the expenditure behind PSIS has been increased [24].

Identifying the significance of PSIS, Rocheleau [39] suggests that although public sector organizations spend much money on IT, it might appear that the organization suffers from a lack of motivation while IS in the public sector organization plays a vital role in identifying the factors underlying this. Heeks [18] identified the role of PSIS in dealing with four important aspects: monitoring and controlling information 
about what has happened and what is happening instead of what will happen; evaluating through simple techniques; feeding evaluation reports into decision making processes and focusing on operational and tactical aspects. Thus, although PSIS is an underutilized field, it has the potential to deal with organizational contexts and service delivery design [7]. Evidently, a large volume of E-service design relied on E-service framework or models for private sector. Rosacker and Olson [40] note that PSIS have more distinctive features than private sector information systems and therefore while designing information system for public sector organization the role of PSIS is inevitable.

\subsection{PSIS for E-Service in Public Sector Organization}

With the expansion of IT in citizens' expectations about services from public sector organization have increased in terms of quality i.e. convenience, accessibility and affordability; and it terms of quantity i.e. more services within a short span of time and at a 'one stop shop'; and in terms of availability i.e. 24/7. To meet citizens' expectations, every public sector organization has been designing IT applications known as E-service initiatives with view to citizens' easy access [28], [43]. Thus E-service has emerged as a potential field, focusing on designing and redesigning IT and organizational processes of public sector organization. Although every government is striving to deliver E-services successfully, many developing countries have failed to provide effective and efficient E-service for their citizens [1], [2], [28], [45].

In the main, E-service in public sector organization aims to provide citizens' with easy access to services, reduce costs and time and make the service more convenient. It is not merely a technological issue; rather it is closely connected with organizational, social, economic and user contexts [15]. Thus, designing E-Service applications in public sector organizations is complex and involves many phases, processes, actors, roles and practices [15], [25], [34]. Consequently, technological design alone cannot ensure effective and efficient public services [9].

The range and nature of E-services is very wide, including unidirectional broadcasting to highly interactive communication involving clients, staff, workflow systems, data-bases and specially designed interaction software [15]. E-services include kiosks, telecentres, call centers, web portals and front offices or other means. However, designing and managing E-services requires citizens' familiarity with the services, convenient, flexibility in choices; easy accessibility; equality between e-service and non e-services and effective use of information [9]. Taken together, this paper argues that PSIS offers potential as a lens to understand organizational processes, contexts, users' capability and attitude of organizational staff in order to design E-services for public sector organizations. Therefore, this paper applies PSIS to designing E-service for land records in Bangladesh public sector organizations. 


\section{$5 \quad$ E-service for Land Records in Bangladesh}

Bangladesh is a least developed country located between India and Myanmar. It is the most population dense country in the world with a total of 160 million people; it has high rates of illiteracy, very low electronic literacy and access to technology. It is mainly agro-based country with a visible land scarcity; an average land per person is 0.22 acre only. In addition to, its $80 \%$ of people live in rural areas; a total $70 \%$ of people agriculturists and agriculture contributes to $60 \%$ of total GDP. Thus land and land records related services are significant. Land records services are delivered from public sector organizations. Land records are inevitably needed for legal, financial, welfare services, development planning, and transfer of land ownership, determination of ownership and size of land parcels and resolving of land litigations. Thus service delivery of land records has become a core service to citizens from the public sector organizations.

Service delivery of land records refers to issuing a certified copy of a land records from the District Record Room (DRR) to citizens. Daily about 20,000-30,000 applications are received by public sector organizations, the DRRs, for service delivery of land records. The district under study receives about 300-400 applications per day.

This service has been identified as ineffective, corruptive, cause of public sufferings and middlemen dependent. Consequently, designing and implementing E-service has been identified as an important mechanism for making this service effective, bringing this service at the citizens' door step and removing complicacy and middlemen from this service.

\subsection{Organizational Context for Land Records E-service}

Although Bangladesh gained independence from Pakistan in 1971, it had previously been under British Colonial Rule from 1757 to 1947. The land records and its service delivery was introduced by the Colonial government in the country, thus it inherited and to some extent still relies on the colonial rules, regulation and statues in particular related to land services. In addition, land records services has been identified as the top ranked sector for corruption; a major source of litigation and a sector for intolerable public suffering [21]. Further, this service follows archaic service delivery processes, dilapidated conditions of the printed land records and registers; complicated systems land records and this service delivery is controlled by strong bureaucratic processes. Together, these have given rise to rampant rent seeking vested interests of staff and middlemen's corruption network for mediating this service.

Thus with a view to ensuring easier access for citizens to the land records service, the government of the day has launched E-service for land records. The government designed a flagship program, 'Access to Information (A2I)', directed from the Prime Minister's office. A2I has designed three electronic access points to ensure citizens easy access to the land record service. These are telecentres known as Union Information Service Center (UISC), front desk known as E-service Center (ESC) and District Web Portal (DWP) (See figure-1). Thus, the E-service for land records has designed a country wide technological network comprising 4501 telecentres, 64 front 
desks (one in each district) and 64 district web portal (one in each district), aiming to ensure citizens' easier access this service. However, the organizational contexts and processes, merely accepts the technological design of the E-service of land records.

The land records service evolved from printed land records, which appeared during the British colonial regime at the end of the 20th century. The DRR is entrusted with the responsibility for preserving land records and providing service delivery of land records. In 1950, the feudal system (Landlords - Zamindars) was abolished. Thereafter, the tenants, the cultivators, became the land owners. Consequently, land records turned into valuable documents for the citizens. A certified copy of a land record is required proof of ownership and land records become a compulsory element for related services: land purchase, sales, mortgages, taxation, land litigation, infrastructural planning and development.

From the colonial regime to now, there are up to three versions of land records for each plot of land. The first version was prepared by the British colonial rulers in 1920s. When land ownership changed from landlord to tenants in the 1950s during Pakistan's regime, another version of land record was prepared. Bangladesh gained its independence from Pakistan in 1971. Thereafter the third version of land records preparation started and it is not completed yet. As a result, each plot of land may have three versions of records and surprisingly, all of the versions are active records for proof of ownership of a plot of land. Notably, the majority of the population is illiterate. So they do not know their land records ID numbers and the versions of land records. Consequently, citizens cannot submit their application through the E-service access points. During the interviews one staff member mentioned, "The E-service has designed this E-service which can be compared with a nice garden with several entrance points but its visitors are blind".

As a result, out of the three access points, telecentres and DWPs remain underutilized (see figure -1). The front desk, the ESC was designed to receive online application, but as citizens could not submit their online application, the ESC has turned to paper based applications, similar to the previous systems. Consequently middlemen and corruption network between staff and middlemen remain same. Eventually the Eservice has increased corrupt processes. 


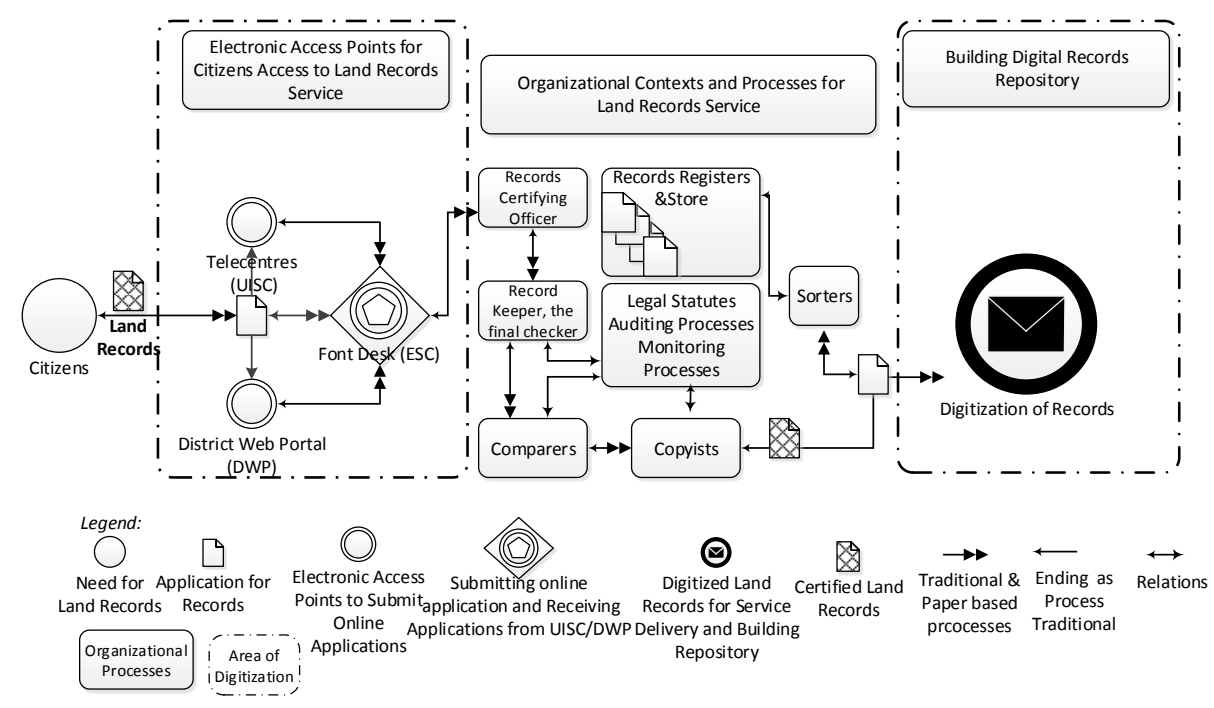

Fig. 1. E-service contexts and processes in the District Record Room (DRR) - a public sector organization

On the other hand, although each rural local Union Council has telecentres that are connected to the DRR and citizens could submit their applications from the telecentres to the DRR. However, citizens rarely accessed to the land records service to the telecentres. Because of, citizens found that traditional middlemen who are based at district headquarters have strong network with the DRR staff to expedite this service delivery.

Thus, setting multiple access points for citizens' easy access to this service is technologically possible. However, the organizational contexts interpreted the technological design of the E-service its own way. The E-service of land records in the organizational contexts every application requires printed copy of online application along with adhesive stamps as fees. Therefore, after electronic submission of applications from a telecentre or citizens needs to print online submitted application form and send it to the DRR along with appropriate fees. Consequently, although from technological point of view, telecentres are easy accessible to the E-service of land records, it has become most difficult due to organizational processes and contexts.

In addition to, citizens have no middlemen network to pay 'bribes' or 'speed money' to the DRR staff to expedite this E-service while they submit applications through the telecentre and the DWP. Moreover, DRR staff do not take 'bribes'/ 'speed money' except from the middlemen networks. Thus without a 'bribe' or 'speed money' applications submitted by citizens through a telecentre or DWP for the E-service land records are either delayed or are found to be missing from the DRR. It is open secret that without a 'bribe' or speed money, this service will not be processed. Furthermore, the organizational processes and required information for submitting application for Eservice of land records are so complex that citizens must rely on middlemen to mediate the land records E-service. 


\section{Implications for PSIS in Designing Land Records E-service}

From the case discussed above, the following implications can be drawn for designing E-service for land records whereby the role of PSIS is inevitable.

\subsection{Absence of Organizational Contexts}

This E-service has been designed without taking into account of the organizational contexts. The land records are complicated and have many different versions. Citizens are often not aware about the ID numbers for land records and the differing versions of land records. Consequently, it is difficult for citizens to apply for land records through E-service.

\subsection{Statutes and Practices}

Legal statutes and practices cannot be designed and changed overnight, but it is possible to design IT. In this case, the E-service has been designed without changing legal statutes. Although this service has designed online application submission process, it requires manual fees submission process i.e. stamps. Besides, for the auditing purpose it needs printed copy of online applications.

Moreover, this design also has failed to account behavioral resistance from the staff and middlemen. Thus without removing the middlemen and corruption network between the middlemen and the staff, the E-service network has been deployed.

Furthermore, the staff have been receiving bribes or speed money for this service for a long time. Consequently, only setting of E-service network cannot remove their relations with the middlemen who manage the 'speed money' (bribes) from citizens. Thus, without excluding the processes that provide opportunities for speed money, designing the E-service is practically worthless. Although the telecentres and the DWP have been designed for citizens' access to this service, citizens found that these are not effective to receive 'speedy service'. Thus, they return to the traditional processes, which is the middlemen network. Finally middlemen have adapted themselves through submitting citizens' application through the 'Front Desk' known as E-service Center (ESC) to continue mediation of this service. It has become possible because the organizational processes are in favor of the middlemen and any other methods of submissions are resisted by the staff.

\subsection{Users' Capability and Organizational Reality}

The users of the E-service are mostly farmers who are mainly illiterate. Thus filling online applications with appropriate land records ID numbers, understanding different versions of land records and the jurisdiction number for land records are difficulties for them. Besides, setting of website, DWP, for submitting online land records applications is unrealistic where only $0.35 \%$ of the population has internet access. In addition, the low literacy and electronic literacy and limited connectivity and accessibility 
to computer and internet are prevalent across the country. Consequently, the E-service has hardly made any improvement in citizens' access to this service. This E-service has been designed from technological viability any change in organizational contexts. As a result, although electronic access points have been setup, they did not remove the organizational problems; rather the organizational problems have reshaped the Eservice.

\subsection{Monitoring and Evaluation}

Although the DWP has failed to ensure citizens' easier access to the DRR, the advantages of this access point has been harnessed by the organizational staff and middlemen to provide better services to their clients who provide bribes. Because of, the staff have good internet connections and printers, so they use it for submitting online applications via DWP on behalf their middlemen.

On the other hand, unsurprisingly, although the aim of the E-service centers (the front desk) was to be an access point for those citizens visiting the district headquarters. However, instead it has become the access point for middlemen who submit paper based application via this service. Thus, the underlying organizational contexts and practices have been continuously redesigning the E-service. Finally, this Eservice has no means continuous monitoring and evaluation.

\section{Conclusion}

This paper has illustrated the case of E-services in public sector organizations in a developing country. Successful implementation of E-services in general is difficult and in developing countries is a great challenge. The failure rate for E-service projects in developing countries is very high and existing E-governance approaches have largely failed to address the problems. Many scholars have already looked at finding alternative streams or alternatives to E-governance for designing and implementing Eservices in public sector organizations. This paper has argued that there is need for public sector information systems (PSIS), as a dedicated field of IS for designing and evaluating E-services for public sector organizations. One of the defining characteristics for this is the strong emphasis on taking into account the organizational context during the design and implementation process.

In conclusion it can be said that E-service in public sector organization cannot succeed without taking into account the organizational contexts, statutes and practices. PSIS has become an inevitable part of the design, monitoring and evaluation of Eservice in public sector organizations. More recently public sector E-service organizations are modelling themselves on private sector E-services. Since the context of the public sector organization is significantly different from private sector organizations, a public sector information systems (PSIS) offers the potential to deal with the contexts, practices, users, organizational reality, resources, rules, regulations and statutes of the public sector organization in designing E-service. 


\section{References}

1. Alam, M. S., Brooks, L., Abbott, P.: Action Design Ethnographic Research - in Search of a Rigorous Methodology for IS Research. (2012)

2. Alam, M. S., Brooks, L., Khan, N. I.: Action Design Ethnographic Research (ADER): Vested Interest Networks and ICT Networks in Service Delivery of Land Records in Bangladesh. (2012) 51-67

3. Axelsson, K., Melin, L., Lindgren, I.: Public e-Services for Agency Efficiency and Citizen Benefit - Findings from a Stakeholder Centered Analysis. Government Information Quarterly, 30 (2013) 10-22

4. Beck, R., Weber, S., Gregory, R.: Theory-Generating Design Science Research. Information Systems Frontiers, 15 (2013) 637-651

5. Bhuiyan, M. S. H.: Public Sector eService Development in Bangladesh: Status, Prospects and Challenges. Electronic Journal of e- Government, 9 (2011) 15-29

6. Chen, Y., \& Khosrow-Pour, M.: Digital Government Development. In: KhosrowPour, M. (ed.) Encyclopedia of E-Commerce, E-Government, and Mobile Commerce, pp. 203-209. IGI Global, Hershey, PA (2006)

7. Cordella, A., \& Iannacci, F.: Information Systems in the Public Sector: The eGovernment Enactment Framework. The Journal of Strategic Information Systems, 19 (2010) 52-66

8. Davis, G. B., \& Olson, M. H.: Management information systems: Conceptual foundation, structure and development. 2nd edn. McGraw-Hill, New York (1985)

9. Donnelly, P., \& McGuirk, T.: Electronic Delivery of Public Services in the United Kingdom: The Case of the Merseyside Fire Service and Fire Service Direct. Asian Journal of Public Administration, 25 (2003) 185-208

10. Dunleavy, P.: Organisation and state organisation in digital era. In: Mansell, R., Avgerou, C., Quah, D., et al (eds.) The Oxford handbook of information and communication technologies. Oxford University Press, Oxford (2007)

11. Dunleavy, P., Margetts, H., Tinkler, J.: New Public Management is dead-long Live Digital-Era Governance. Journal of Public Administration Research and Theory, 16 (2005) 467-494

12. Farazmand, A.: Privatisation Or Reform? Public Enterprise Management in Transition. International Review of Administrative Sciences, 65 (1998) 551-567

13. Gershon, P.: Releasing Resources to the Front Line: Independent Review of Public Sector Efficiency. (2004)

14. Gil-Garcia, J. R., \& Martinez-Moyano, I. J.: Understanding the Evolution of eGovernment: The Influence of Systems of Rules on Public Sector Dynamics. Government Information Quarterly, 24 (2007) 266-290

15. Gronlund, A.: Managing electronic services: A public sector perspective. Springer, London (2000)

16. Heeks, R.: Most E-Government for Development Project Fail: How can Risk be Reduced?, iGovernment Working Paper Series, Paper no. 14. (2003)

17. Heeks, R.: Information System in Developing Countries: Failure, Success and Local Improvisations. The Information Society, 18 (2002) 101-112

18. Heeks, R.: Public Sector Management Information Systems. (1998)

19. Heeks, R.: Reinventing government in the information age : International practice in IT-enabled public sector reform. Routledge (2002) 
20. Imran, A., \& Gregor, S.: Uncovering the Hidden Issues in E-Government Adoption in a Least Developed Country: The Case of Bangladesh. Journal of Global Information Management, 18 (2010) 30-56

21. Imran, A., \& Gregor, S.: Vested Interests Obstructing Information Systems use: Land Administration in a Least Developed Country (2011) 1-24

22. Institute for Government: System error: Fixing the flaws in government IT. Institute for Government, London (2010)

23. Irani, Z., Love, P. E. D., Montazemi, A.: E-Government: Past, Present and Future. European Journal of Information Systems, 16 (2007) 103-105

24. Jones, S.: Social Dimension of IT/IS Evaluation: Views from the Public Sector. In: Irani, Z. and Love, P.E.D. (eds.) Evaluating Information Systems: Public and Private Sector, pp. 236-256. Butterworth-Heinemann, Oxford (2008)

25. Liikanen, E.: Backflap. In: Gronlund, A. (ed.) Managing Electronic Services: A Public Sector Perspective. Springer, London (2000)

26. Lindgren, I., \& Jansson, G.: Electronic Services in the Public Sector: A Conceptual Framework. Government Information Quarterly, 30 (2013) 163-172

27. Lips, M.: E-Government is Dead: Long Live Public Administration 2.0. Innovation in the Public Sector, 20 (2013) 30-41

28. Lofstedt, U.: E-Government - Assessment of Current Research and some Proposals for Future Directions. International Journal of Public Information Systems, 1 (2005) 39-52

29. McCourt, W.: New public management in developing countries. In: McLaughlin, K., Osborne, S.P. and Ferlie, E. (eds.) New Public Management: Current Trends ands Future Prospects. Routledge (2002)

30. Melin, U., \& Axelsson, K.: Managing E-Government Projects: A Comparative Case Study of Two Inter- Organizational E-Service Development Initiatives. (2008) 1716-1727

31. Niederman, F., \& March, S. T.: Design Science and the Accumulation of Knowledge in the Information Systems Discipline. Journal ACM Transactions on Management Information Systems, 3 (2012)

32. Nygren, K. G., Axelsson, K., Melin, U.: Public e-Services from Inside: A Case Study on Technology's Influence on Work Conditions in a Government Agency. International Journal of Public Sector Management, 26 (2013) 455-468

33. O'Leary, R., Gerard, C., Bingham, L. B.: Introduction to the Symposium on Collaborative Public Management. Public Administration Review, 66 (2006)

34. OECD: Service Delivery in Fragile Situations : Key Concepts, Findings and Lessons Journal of Development, 9 (2008)

35. Orlikowski, W. J.: The Duality of Technology: Rethinking the Concept of Technology in Organizations. Organization Science, 3 (1992) 398-427

36. Orlikowski, W. J., \& Iacono, C. S.: Research Commentary: Desperately Seeking the 'IT' in IT Research--A Call to Theorizing the IT Artifact. Information Systems Research, 12 (2001) 121

37. Persson, A., Axelsson, K., Melin, U.: E-Government Challenges - Exploring Inter-Organisational Aspects of e-Service Development. . (2006) 1419-1430

38. Pollitt, C., \& Bouckaert, G.: Public management reform. Oxford University Press, Oxford (2004) 
39. Rocheleau, B.: Evaluating Public Sector Information Systems: Satisfaction Versus Impact. Eval. Program Plann., 16 (1993) 119-129

40. Rosacker, K. M., \& Olson, D. L.: Public Sector Information System Critical Success Factors. Transforming Government: People, Process and Policy, 2 (2008) 60-70

41. Sahay, S.: Implemenation of Information Technology: A Time-Space Perspective. Organisation Studies, 8 (1997) 229-260

42. Sahay, S., \& Robey, D.: Organizational Context, Social Interpretation, and the Implementation and Consequences of Geographic Information Systems. Accounting, Management and Information Technologies, 6 (1996) 255-282

43. Scholl, H. J.: Introduction to the Electronic Government Cluster of Minitracks . (2004)

44. Sein, M. K., Henfridsson, O., Purao, S. et al.: Action Design Research. MIS Quarterly, 35 (2011) 37-56

45. Sleeman, B.: Recent Literature on Government Information. Journal of Government Information, 30 (2004) 20-41

46. Varney, D.: Service Transformation: A Better Service for Citizens and Businesses, a Better Deal for the Taxpayer. (2006)

47. Walsham, G.: Interpreting information systems in organizations. Wiley, Chichester (1993)

48. Yildiz, M.: E-Government Research: Reviewing the Literature, Limitations, and Ways Forward. Government Information Quarterly, 24 (2007) 646-665

49. Yildiz, M., \& Saylam, A.: E-Government Discourses: An Inductive Analysis. Government Information Quarterly, 30 (2013) 141-153 